\title{
Selection of Herbicides TaRgeting the Use in Crop Systems Cultivated with Showy Crotalaria ${ }^{1}$
}

\author{
Seleção de Herbicidas Visando ao Uso em Sistemas Cultivados com Crotalária
}

\author{
BRAZ, G.B.P. ${ }^{2}$, OLIVEIRA JR., R.S. ${ }^{2}$, CONSTANTIN, J. ${ }^{2}$, TAKANO, H.K. ${ }^{2}$, CHASE, C.A. ${ }^{3}$, \\ FORNAZZA, F.G.F. ${ }^{2}$, and RAIMONDI, R.T. ${ }^{2}$
}

\begin{abstract}
The increase in the area planted with Crotalaria spectabilis has occurred by several factors, highlighting the potential to reduce the nematodes, nitrogen fixation and the high production of biomass. By becoming a species sown as a crop, it is necessary to control the weeds that coexist with showy crotalaria. This change in the use of this crop creates the possibility of this specie becoming a weed. The aim of this study was to assess the potential use of herbicides applied in preemergence and postemergence of $C$. spectabilis for different purposes (control of volunteer and selectivity plants). Three experiments were installed in a greenhouse (two with herbicides applied in preemergence - in soils with distinct textural categories; and one experiment with herbicides applied in postemergence). The results of the experiments with herbicides applied in preemergence showed that: amicarbazone, atrazine, diuron, metribuzin, prometryn, fomesafen and sulfentrazone showed effectiveness for control of $C$. spectabilis in clayey soil. Besides these, flumioxazin and isoxaflutole also showed potential to be used in the control of showy crotalaria in soils with loam texture. In relation to the postemergence herbicides, atrazine, diuron, prometryn, flumioxazin, fomesafen, lactofen, saflufenacil, amonio-glufosinate and glyphosate can be used aiming the chemical control of $C$. spectabilis. Herbicides chlorimuron-ethyl, diclosulan, imazethapyr, pyrithiobac-sodium, trifloxysulfuron-sodium, clomazone, pendimethalin, S-metolachlor and trifluralin applied in preemergence, and imazethapyr, pyrithiobac-sodium, flumiclorac, bentazon and clethodim applied in postemergence caused low levels of injury to C. spectabilis plants, making necessary the development of new searches to ensure the selectivity of these products.
\end{abstract}

Keywords: selectivity, control of volunteer plants, crop rotation, Crotalaria spectabilis.

RESUMO - O acréscimo da área plantada com Crotalaria spectabilis tem ocorrido por diversos fatores, destacando-se o potencial de redução de nematoides, fixação de nitrogênio e elevada produção de biomassa. Ao se tornar espécie semeada como cultura, faz-se necessário o controle de plantas daninhas que convivem com a crotalária. Essa mudança na utilização dessa cultura cria a possibilidade de a espécie se tornar planta daninha. O objetivo deste trabalho foi de avaliar o potencial de utilização de herbicidas aplicados em pré e pós-emergência de C. spectabilis para diferentes finalidades (controle de plantas voluntárias e seletividade). Foram instalados três experimentos em casa de vegetação (dois com herbicidas aplicados em pré-emergência-em solos de classes texturais distintas; e um experimento com herbicidas de pós-emergência). Os resultados dos experimentos com herbicidas aplicados em pré-emergência permitiram concluir que: amicarbazone, atrazine, diuron, metribuzin, prometryn, fomesafen e sulfentrazone apresentaram eficácia para controle de $\mathbf{C}$. spectabilis em solo argiloso. Além desses flumioxazin e isoxaflutole também apresentaram potencial para serem usados no controle de crotalária, em solos de textura franco-argiloarenosa. Com relação à aplicação de herbicidas em pós-emergência, atrazine, diuron, prometryn, flumioxazin, fomesafen, lactofen, saflufenacil, amonio-glufosinate e glyphosate podem ser utilizados visando o controle quimico de C. spectabilis. Os herbicidas chlorimuron-ethyl, diclosulan, imazethapyr, pyrithiobac-sodium,

1 Recebido para publicação em 29.1.2015 e aprovado em 7.4.2015.

2 Universidade Estadual de Maringá (UEM/NAPD), Maringá, PR, Brasil, < guilhermebrag@gmail.com>; 3 University of Florida, Gainesville, FL, Estados Unidos. 
trifloxysulfuron-sodium, clomazone, pendimethalin, S-metolachlor e trifluralin, aplicados em pré-emergência, e imazethapyr, pyrithiobac-sodium, flumiclorac, bentazon e clethodim, aplicados em pós-emergência, causaram baixos niveis de injúrias às plantas de C. spectabilis, sendo necessário o desenvolvimento de novas pesquisas para assegurar a seletividade deles.

Palavras-chave: seletividade, controle de plantas voluntárias, rotação de culturas, Crotalaria spectabilis.

\section{INTRODUCTION}

Historically, the wide acceptance of monocrop by farmers occurs depending on the choice of crops that offer higher profitability when marketing the final yield, which makes that the sustainability of the agricultural system is not taken into account in planning the rotation of the species to be cultivated. From an agricultural point of view, this practice negatively undertakes various factors of the production environment because it reduces the diversity of the organisms that make up the microfauna of the soil, increases the pressure of pests, diseases and weeds, and reduces the residual activity of herbicides (Gasparim et al., 2005; Zablotowicz et al., 2006).

In addition to the losses generated by monocrop, when comparing this with the systems in which the diversification of crop practices is used, such as intercropping and rotation, negative effects are also observed on the edaphic environment, whereas in conservation systems there are benefits such as further exploration of the soil profile (species with root systems of different depths), higher nutrient cycling in the soil and straw formation for the no-tillage system (Balesdent et al., 2000). When opting by the practice of crop rotation, previously it is necessary to observe some factors such as the potential that rotated species present in hosting the same pests, phytonematodes and pathogens, the existence of allelopathic effects of a crop for which sowing is rotated, as well as the risk of a species becoming a weed to the other (Peixoto et al., 2007; Braz et al., 2013).

Among the crops that showed an increase in the cultivated area aimed for crop rotation in fields sown with soybeans, maize, sugarcane and cotton, $C$. spectabilis has stood out mainly because of its capacity for reduction of phytonematodes infestation, nitrogen fixation and high biomass yield. C. spectabilis is a slow growth annual legume, being a medium-sized shrubby plant $(0.60$ to $1.50 \mathrm{~m})$, which has deep taproot, able to break compacted layers (Barreto \& Fernandes, 2001). The low initial rate of growth and the small size of this species provide crop in higher plant density per area (Carvalho et al., 2003); on the other hand, its favor the emergence and development of weeds throughout the cycle, which reduces the yield of this species.

Being a species that is still in the insertion phase, aiming its use in crop rotation, factors relating to the cultivation of C. spectabilis need to be adjusted so that the presence of this species does not cause any damage to the agricultural system in which it will be inserted. Among these factors are the ones related to the need for weed control in the areas cultivated with showy crotalaria, for if tillage practices are not adopted, it will be a crop in which will occur increase in seedlings of weeds. In addition, there is also the need to seek alternatives to control volunteer plants of showy crotalaria in rotation crops in order to prevent these species from becoming a weed.

To improve these practices, conducting studies for the selection of herbicides is needed for both purposes (control of volunteer plants of $C$. spectabilis and selectivity for this species), because after this kind of information is adjusted, the inclusion of a new crop within in the agricultural production system becomes less risky. Herbicide selection studies for crops that are being placed in new systems consist in screening different mechanisms of action assessed in various doses (screening herbicides); from the results, they are positioned for the purpose according to the potential shown by each active ingredient (Monquero, 2005). 
Similarly to showy crotalaria, pearl millet cultivation increased in planted area due to the phytonematodes reduction potential, and studies were conducted searching herbicides that were selective for its, as well as others that showed effectiveness in controlling the species (Dan et al., 2011). Examples of herbicide screening work for various crops are available in the literature, such as for castor beans plant (Ricinus communis) and crambe (Maciel et al., 2011; Oliveira Neto et al., 2011a). For C. spectabilis there are few reports of this type of research, and just a few studies on the control of this species carried out in the United States, where it is classified as weed (Wills \& McWhorter, 1981; Maddox et al., 2001).

From this context, this study aimed to assess the potential use of herbicides applied in preemergence and postemergence of C. spectabilis for different purposes (control of volunteer plants and selectivity).

\section{MATERIAL AND METHODS}

Three experiments were conducted in a greenhouse, whose geographic coordinates are $23^{\circ} 24^{\prime} 12$ "S and $51^{\circ} 56^{\prime} 24^{\prime \prime} \mathrm{W}$, with an altitude of $560 \mathrm{~m}$. Experiments 1 and 2 (E1 and E2) consisted in the assessment of herbicides applied in preemergence of $C$. spectabilis (E1 clayey texture soil; E2 - loam texture soil), whereas in experiment 3 (E3) applications were performed in postemergence of the species. The period of performance of E1 and E2 was from 04/03/2012 to 05/10/ 2012 , and of E3, from $10 / 27 / 2012$ to $12 / 14$ / 2012.

\section{Experiments 1 and 2 (E1 and E2) - Herbicides applied in preemergence}

The experimental units were composed of $3 \mathrm{dm}^{3}$ pots. Each experiment was conducted in a texture soil category and these are classified as clayey and loam. The physicochemical characteristics of the soil for E1 were: $\mathrm{pH}_{\mathrm{H} 2 \mathrm{O}}=5.3 ; 17.05 \mathrm{~g} \mathrm{dm}^{-3}$ of organic matter $(\mathrm{OM})$; $520 \mathrm{~g} \mathrm{~kg}^{-1}$ of sand; $100 \mathrm{~g} \mathrm{~kg}^{-1}$ of silt; and $380 \mathrm{~g} \mathrm{~kg}^{-1}$ of clay. The physicochemical characteristics of the soil for E2 were: $\mathrm{pH}$ $\left(\mathrm{H}_{2} \mathrm{O}\right)=6.2 ; 22.46 \mathrm{~g} \mathrm{dm}^{-3}$ of $\mathrm{OM} ; 680 \mathrm{~g} \mathrm{~kg}^{-1}$ of sand; $80 \mathrm{~g} \mathrm{~kg}^{-1}$ of silt; and $240 \mathrm{~g} \mathrm{~kg}^{-1}$ of clay.
The experimental design used in both experiments was entirely randomized, with four replications. The experiments were implemented in a $(19 \times 3)+1$ factorial arrangement. The first factor corresponded to different herbicides applied in preemergence of the showy crotalaria (Table 1); and the second one to the doses of each herbicide, equivalent to 100,50 and $25 \%$ of the highest dose recommended for the crops for which these yields have a log (dose in Table 1 is equivalent to $100 \%$ ). The additional treatment consisted in a check without herbicide, which served as a comparison for the visual assessments of phytotoxicity.

Sowing of $C$. spectabilis was done on 04/03/2012, placing the seeds $1-2 \mathrm{~cm}$ deep from the soil surface, distributing 15 seeds per pot. The reason for carrying out the sowing of the same number of seeds per pot is related to the stand assessments. After seeding showy crotalaria, the pots were irrigated daily with levels ranging between 5 and $10 \mathrm{~mm}$ and kept free from the presence of other plants.

Table 1 - Relationship of treatments assessed in applications in preemergence aiming to select herbicides to be used in systems cultivated with C. spectabilis. Maringá, PR - 2012

\begin{tabular}{|c|c|c|}
\hline Treatment & $\begin{array}{c}\text { Dose } \\
\left(\mathrm{g} \mathrm{ha}^{-1}\right)^{*}\end{array}$ & Mechanism of action \\
\hline Chlorimuron-ethyl & 20 & \multirow{6}{*}{ ALS inhibitors } \\
\hline Diclosulan & 35.28 & \\
\hline Flumetsulan & 120 & \\
\hline Imazethapyr & 106 & \\
\hline Pyrithiobac-sodium & 84 & \\
\hline Trifloxysulfuron-sodium & 7.5 & \\
\hline Flumioxazin & 60 & \multirow{3}{*}{ PROTOX inhibitors } \\
\hline Fomesafen & 375 & \\
\hline Sulfentrazone & 600 & \\
\hline Clomazone & 800 & \multirow{2}{*}{$\begin{array}{l}\text { Inhibitors of the } \\
\text { carotenoids synthesis }\end{array}$} \\
\hline Isoxaflutole & 60 & \\
\hline Pendimethalin & 1500 & \multirow{3}{*}{ Cell division inhibitors } \\
\hline S-metolachlor & 1728 & \\
\hline Trifluralin & 2250 & \\
\hline Amicarbazone & 280 & \multirow{5}{*}{$\begin{array}{l}\text { Inhibitors of photosystem } \\
\text { II }\end{array}$} \\
\hline Atrazine & 2500 & \\
\hline Diuron & 2000 & \\
\hline Metribuzin & 480 & \\
\hline Prometryn & 1000 & \\
\hline
\end{tabular}

* Higher dose recorded for use in crops for which the herbicide is recorded (Rodrigues \& Almeida, 2011). 
Applications were carried out in preemergence, immediately after sowing showy crotalaria. In all applications was used a backpack sprayer with $\mathrm{CO}_{2}$ based constant pressure, equipped with a boom equipped with three tips with flat fan XR-110.02 nozzles, spaced $50 \mathrm{~cm}$ apart, under pressure of $2.0 \mathrm{kgf} \mathrm{cm}^{-2}$. Such application conditions gave an equivalent application rate of $200 \mathrm{~L} \mathrm{ha}^{-1}$. At the time of application, weather conditions were: average temperature $=25^{\circ} \mathrm{C}$, average relative humidity $(\mathrm{RH})=80 \%$ and average wind speed $=0.8 \mathrm{~km} \mathrm{~h}^{-1}$, and soil was wet in all experimental units.

The assessments performed were of stand (number of plants per pot) and percentage of phytotoxicity at 7 and 28 days after emergence (DAE), using a percentage scale from 0\% (representing no effect of herbicides on plants) to $100 \%$ (plants total death). In addition, the dry matter of the shoots was determined at 28 DAE, which is obtained after drying the plant in a forced air circulation oven, in which the plants remained during the period of 72 hours on an average temperature of $65^{\circ} \mathrm{C}$.

\section{Experiment 3 (E3) - Herbicides applied in postemergence}

The experimental units were composed of $3 \mathrm{dm}^{3}$ pots. For filling the pots clayey soil was used with the following physicochemical characteristics: $\mathrm{pH}\left(\mathrm{H}_{2} \mathrm{O}\right)=5.8,17.05 \mathrm{~g} \mathrm{dm}^{-3}$ of $\mathrm{OM} ; 520 \mathrm{~g} \mathrm{~kg}^{-1}$ of sand; $100 \mathrm{~g} \mathrm{~kg}^{-1}$ of silt; and $380 \mathrm{~g} \mathrm{~kg}^{-1}$ of clay.

The seeding of $C$. spectabilis was done on $10 / 27 / 12$, placing the seeds at $1-2 \mathrm{~cm}$ deep from the soil surface; about 20 seeds per pot were distributed, and thinning of the seedlings was done after emergence, keeping six plants per experimental unit. After sowing, the pots were irrigated daily with levels ranging between 5 and $10 \mathrm{~mm}$ and kept free of the presence of other species.

The experimental design used was completely randomized, adopting four replicates per treatment. The experiment was conducted in a $(21 \times 3)+1$ factorial arrangement, where the first factor corresponded to different herbicides applied postemergence of showy crotalaria (Table 2), and the second one corresponded to three doses of each herbicide, equivalent to 100,75 and $50 \%$ of the recommended dose for crops for which these products have a log (dose in Table 2 is equivalent to $100 \%$ ). The additional treatment consisted in a check without herbicide, which served as a comparison for the visual assessments of phytotoxicity.

The applications were performed in postemergence on $11 / 19 / 2012$, when the showy crotalaria plants were in a stage of two to four leaves (most with three leaves), with height ranging between 6 to $8 \mathrm{~cm}$. The equipment used in the applications as well as in their adjustments (pressure, number of tips, tip type and application rate) were the same as described in previous experiments. At the time of the application, weather conditions were: average temperature $=26{ }^{\circ} \mathrm{C}$, average $\mathrm{RH}=78 \%$ and average wind speed $=0.8 \mathrm{~km} \mathrm{~h}^{-1}$, and soil was wet in all experimental units.

Table 2 - Relationship of treatments assessed in postemergence applications in order to select herbicides for use in systems cultivated with C. spectabilis. Maringá, PR - 2012

\begin{tabular}{|c|c|c|}
\hline Treatment & $\begin{array}{c}\text { Dose } \\
\left(\mathrm{g} \mathrm{ha}^{-1}\right)^{*}\end{array}$ & Mechanism of action \\
\hline Chlorimuron-ethyl ${ }^{3 /}$ & 20 & \multirow{5}{*}{ ALS inhibitors } \\
\hline Imazethapyr $^{7^{\prime \prime}}$ & 106 & \\
\hline Nicosulfuron $^{-1 /}$ & 60 & \\
\hline Pyrithiobac-sodium ${ }^{5 /}$ & 112 & \\
\hline Trifloxysulfuron-sodium ${ }^{\mathbf{5}}$ & 7.5 & \\
\hline Flumiclorac ${ }^{\underline{2} /}$ & 60 & \multirow{5}{*}{ PROTOX inhibitors } \\
\hline Flumioxazin $^{1 /}$ & 25 & \\
\hline Fomesafen ${ }^{4 /}$ & 250 & \\
\hline Lactofen $^{\text {7/ }}$ & 150 & \\
\hline Saflufenacil $^{1 /}$ & 35 & \\
\hline Mesotrione $^{{ }^{1 /}}$ & 192 & \multirow{2}{*}{$\begin{array}{l}\text { Inhibitors of the } \\
\text { carotenoids synthesis }\end{array}$} \\
\hline Tembotrione $^{-6 /}$ & 100.8 & \\
\hline Atrazine $^{\underline{1 /}}$ & 2500 & \multirow{4}{*}{$\begin{array}{l}\text { Inhibitors of photosystem } \\
\text { II }\end{array}$} \\
\hline Bentazon $^{1 /}$ & 720 & \\
\hline Diuron $^{7 /}$ & 2000 & \\
\hline Prometryn $^{\underline{7} /}$ & 1000 & \\
\hline 2,4 D-amine ${ }^{7^{\prime /}}$ & 1209 & \multirow{2}{*}{ Auxin mimics } \\
\hline Aminocyclopyrachlor $^{7^{\prime \prime}}$ & 60 & \\
\hline Glyphosate $^{7 /}$ & 1944 & EPSPS inhibitors \\
\hline Clethodim $^{1 /}$ & 96 & ACCase inhibitors \\
\hline Glufosinate-ammonium $^{6 /}$ & 500 & GS inhibitors \\
\hline
\end{tabular}

* Higher dose recorded for use in crops for which the herbicide is recorded (Rodrigues \& Almeida, 2011). ${ }^{1 /}$ Added Assist $-0.5 \%$ v. ${ }^{-1}$;

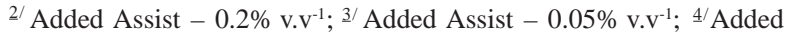
sticker spreader $0.2 \% \mathrm{v} . \mathrm{v}^{-1} ; \underline{5}$ /Added Iharol $-0.5 \% \mathrm{v} \cdot \mathrm{v}^{-1} ;{ }^{6 /}$ Added Aureo $-0.2 \%{\mathrm{v} . \mathrm{v}^{-1}}^{-1}{ }^{\mathbb{1} /}$ Without adding adjuvants to the spray solution. 
The assessment of the percentage of phytotoxicity was done at 3, 7 and 28 days after application (DAA) using a percentage scale of $0 \%$ (representing no effect of herbicides on plants) to $100 \%$ (plants total death). At 28 DAA, the dry matter of the shoot was determined, which is obtained from the same procedures adopted as in experiments with herbicides applied in preemergence.

\section{Statistical analysis}

Data from all experiments were subjected to analysis of variance. When there was significance between factors or among the levels of each factor, Scott-Knott test was applied at $5 \%$ probability $(p<0.05)$. The comparison between treatments and check without herbicide was carried out by Dunnett's test $(\mathrm{p}<0.05)$.

\section{RESULTS AND DISCUSSION}

\section{Experiments 1 and 2 (E1 and E2) - Herbicides applied in preemergence}

Table 3 shows the results of toxicity assessments and $C$. spectabilis plants stand after they were subjected to development in clayey texture soil (E1) with prior application of herbicides in preemergence. Initially (7 DAE), it can be seen that the herbicides that provided greater constraints to the growth of the showy crotalaria seedlings were those having as mechanism of action the inhibition of enzyme protoporphyrinogen oxidase (PROTOX), together with the inhibitors of photosystem II (PSII), all used at the highest dose (D100). It is also observed that the PSII inhibitors (amicarbazone, atrazine, diuron, metribuzin and prometryn) had a smaller reduction in the percentage of phytotoxicity compared to PROTOX inhibitors when applied in smaller doses (D75 and D50).

In the last phytotoxicity assessment, held at $28 \mathrm{DAE}$, it was found that the best treatments aimed at controlling preemergence of C. spectabilis in clayey soil consisted of PSII inhibitors, along with fomesafen and sulfentrazone, since these treatments, when applied in full dose (D100) showed greater than $90.00 \%$ efficiency, besides causing a great reduction in plant stand (Table 3 ).
When one compares the effect of different doses applied, it appears that the only herbicide not having its effectiveness compromised by the use of lower doses is atrazine, which showed similar performance in showy crotalaria control at all doses assessed.

Treatments that showed potential for selective use for $C$. spectabilis in clayey texture soil, applied in preemergence were: chlorimuron-ethyl, imazethapyr, trifloxysulfuron-sodium, pendimethalin and Smetolachlor. These herbicides, besides having provided low levels of phytotoxicity, did not affect the plant stand.

Diclosulan, pyrithiobac-sodium, clomazone and trifluralin are other herbicides with potential for use in showy crotalaria because, although they have provided injuries superior to the ones seen in the above treatments, they had not affected the plant stand either. In the case of herbicides applied in preemergence, various characteristics of the edaphic environment can influence the residual activity of the products, and it is necessary to carry out adjustment studies of doses of each herbicide for the type of soil applied, taking into account the texture, $\mathrm{pH}$, organic matter content and soil moisture (Oliveira Jr. \& Brighenti, 2011).

The dry matter data of the C. spectabilis plants which developed in clayey soil (E1) with prior application of herbicides in preemergence are shown in Table 5. It appears that reductions in the accumulation of this variable had an inverse relationship with the intoxication levels observed in showy crotalaria plants. Amicarbazone, atrazine, diuron, metribuzin, prometryn, fomesafen and sulfentrazone were the treatments that caused greater reduction in dry matter accumulation of showy crotalaria. It should be noted that some treatments, even without providing effective control (>80.00\%), were also able to reduce the mass accumulation of this species. This reduction in the development of C. spectabilis plants results in lower potential for competition with other crop species, since there will be less need for acquisition of resources from the environment (Fialho et al., 2012).

Planta Daninha, Viçosa-MG, v. 33, n. 3, p. 521-534, 2015 
Table 3 - Phytotoxicity (\%) and stand of C. spectabilis plants at 7 and 28 DAE, by applying different herbicides in preemergence in clayey soil (E1). Maringá, PR - 2012

\begin{tabular}{|c|c|c|c|c|c|c|}
\hline \multirow{2}{*}{ Treatment } & \multicolumn{3}{|c|}{ \% of phytotoxicity (7 DAE) } & \multicolumn{3}{|c|}{ \% of phytotoxicity (28 DAE) } \\
\hline & D100 & D50 & D25 & D100 & D50 & D25 \\
\hline Chlorimuron & $29.25 \mathrm{Ab}^{*}$ & $19.75 \mathrm{Bd}$ & $12.25 \mathrm{Bd}$ & $26.25 \mathrm{Ad}^{*}$ & $22.50 \mathrm{Af}$ & $20.50 \mathrm{Ad}$ \\
\hline Diclosulan & $38.00 \mathrm{Ab}^{*}$ & $27.50 \mathrm{Ad}^{*}$ & $16.25 \mathrm{Bd}$ & 38.75 Ac* $^{*}$ & $29.50 \mathrm{Ae}^{*}$ & $16.00 \mathrm{Bd}$ \\
\hline Flumetsulan & $35.50 \mathrm{Ab}^{*}$ & $27.50 \mathrm{Ad}^{*}$ & $18.00 \mathrm{Bd}$ & 37.75 Ac* $^{*}$ & $31.75 \mathrm{Ae}^{*}$ & 18.25 Bd \\
\hline Imazethapyr & $4.75 \mathrm{Ad}$ & $3.75 \mathrm{Ae}$ & $1.25 \mathrm{Ad}$ & $9.25 \mathrm{Ad}$ & $5.00 \mathrm{Af}$ & $3.25 \mathrm{Ad}$ \\
\hline Pyrithiobac & $28.25 \mathrm{Ab}^{*}$ & $24.25 \mathrm{Ad}^{*}$ & $9.75 \mathrm{Bd}$ & $39.50 \mathrm{Ac}^{*}$ & $27.00 \mathrm{Be}^{*}$ & $21.75 \mathrm{Bd}$ \\
\hline Trifloxysulfuron & $22.50 \mathrm{Ac}^{*}$ & $13.25 \mathrm{Ae}$ & $8.00 \mathrm{Ad}$ & $21.50 \mathrm{Ad}$ & $11.75 \mathrm{Af}$ & $11.25 \mathrm{Ad}$ \\
\hline Flumioxazin & $83.75 \mathrm{Aa}^{*}$ & $26.25 \mathrm{Bd}^{*}$ & $10.50 \mathrm{Cd}$ & $73.00 \mathrm{Ab}^{*}$ & $25.00 \mathrm{Be}^{*}$ & $18.00 \mathrm{Bd}$ \\
\hline Fomesafen & $97.25 \mathrm{Aa}^{*}$ & $90.75 \mathrm{Ab}^{*}$ & $47.50 \mathrm{Bb}^{*}$ & $98.50 \mathrm{Aa}^{*}$ & $97.50 \mathrm{Aa}^{*}$ & $33.75 \mathrm{Bc}^{*}$ \\
\hline Sulfentrazone & $91.50 \mathrm{Aa}^{*}$ & $70.00 \mathrm{Bc}^{*}$ & $34.75 \mathrm{Cc}^{*}$ & $93.00 \mathrm{Aa}^{*}$ & $52.50 \mathrm{Bd}^{*}$ & $25.00 \mathrm{Cc}^{*}$ \\
\hline Clomazone & $35.50 \mathrm{Ab}^{*}$ & $27.50 \mathrm{Ad}^{*}$ & $25.00 \mathrm{Ac}^{*}$ & 28.75 Ac* $^{*}$ & $28.75 \mathrm{Ae}^{*}$ & $31.25 \mathrm{Ac}^{*}$ \\
\hline Isoxaflutole & $30.00 \mathrm{Ab}^{*}$ & $29.25 \mathrm{Ad}^{*}$ & $33.00 \mathrm{Ac}^{*}$ & $41.25 \mathrm{Ac}^{*}$ & $35.50 \mathrm{Ae}^{*}$ & $39.25 \mathrm{Ac}^{*}$ \\
\hline Pendimethalin & $35.75 \mathrm{Ab}^{*}$ & $20.00 \mathrm{Bd}$ & $12.00 \mathrm{Bd}$ & $33.25 \mathrm{Ac}^{*}$ & $18.75 \mathrm{Bf}$ & $12.00 \mathrm{Bd}$ \\
\hline S-metolachlor & $18.25 \mathrm{Ac}$ & $18.75 \mathrm{Ad}$ & $11.75 \mathrm{Ad}$ & 20.75 Ad & $17.00 \mathrm{Af}$ & $12.50 \mathrm{Ad}$ \\
\hline Trifluralin & $33.25 \mathrm{Ab}^{*}$ & $20.25 \mathrm{Bd}$ & $10.25 \mathrm{Bd}$ & $32.50 \mathrm{Ac}^{*}$ & $26.25 \mathrm{Ae}^{*}$ & $16.25 \mathrm{Ad}$ \\
\hline Amicarbazone & $98.25 \mathrm{Aa}^{*}$ & $72.50 \mathrm{Bc}^{*}$ & $32.00 \mathrm{Cc}^{*}$ & $99.75 \mathrm{Aa}^{*}$ & $82.50 \mathrm{Bb}^{*}$ & $38.75 \mathrm{Cc}^{*}$ \\
\hline Atrazine & $99.00 \mathrm{Aa}^{*}$ & $99.00 \mathrm{Aa}^{*}$ & $99.00 \mathrm{Aa}^{*}$ & 99.75 Аa* $^{*}$ & $99.75 \mathrm{Aa}^{*}$ & $99.75 \mathrm{Aa}^{*}$ \\
\hline Diuron & $98.50 \mathrm{Aa}^{*}$ & $99.50 \mathrm{Aa}^{*}$ & $53.50 \mathrm{Bb}^{*}$ & $99.75 \mathrm{Aa}^{*}$ & $100.00 \mathrm{Aa}^{*}$ & $28.75 \mathrm{Bc}^{*}$ \\
\hline Metribuzin & $93.50 \mathrm{Aa}^{*}$ & $83.25 \mathrm{Ab}^{*}$ & $38.75 \mathrm{Bc}^{*}$ & $100.00 \mathrm{Aa}^{*}$ & $99.75 \mathrm{Aa}^{*}$ & $64.50 \mathrm{Bb}^{*}$ \\
\hline Prometryn & 99.00 Aa* & $63.75 \mathrm{BC}^{*}$ & $25.00 \mathrm{CC}^{*}$ & 99.25 Aa* & $67.00 \mathrm{BC}^{*}$ & $20.00 \mathrm{Cd}$ \\
\hline Check & \multicolumn{3}{|c|}{0.00} & \multicolumn{3}{|c|}{0.00} \\
\hline CV (\%) & \multicolumn{3}{|c|}{22.06} & \multicolumn{3}{|c|}{23.97} \\
\hline \multirow{2}{*}{ Treatment } & \multicolumn{3}{|c|}{ Stand (7 DAE) } & \multicolumn{3}{|c|}{ Stand (28 DAE) } \\
\hline & D100 & D50 & D25 & D100 & D50 & D25 \\
\hline Chlorimuron & $10.25 \mathrm{Aa}$ & $9.50 \mathrm{Aa}$ & $11.75 \mathrm{Aa}$ & $10.50 \mathrm{Ba}$ & $9.25 \mathrm{Ba}$ & $12.50 \mathrm{Aa}$ \\
\hline Diclosulan & $8.00 \mathrm{Ab}$ & $7.75 \mathrm{Ab}$ & $9.50 \mathrm{Aa}$ & $8.25 \mathrm{Ab}$ & $8.00 \mathrm{Aa}$ & $9.75 \mathrm{Aa}$ \\
\hline Flumetsulan & 10.25 Аа & $9.25 \mathrm{Aa}$ & $8.50 \mathrm{Aa}$ & 10.25 Аа & 8.75 Аа & $9.50 \mathrm{Aa}$ \\
\hline Imazethapyr & $8.50 \mathrm{Ab}$ & $10.25 \mathrm{Aa}$ & $10.25 \mathrm{Aa}$ & $8.75 \mathrm{Ab}$ & $10.00 \mathrm{Aa}$ & $10.50 \mathrm{Aa}$ \\
\hline Pyrithiobac & $8.50 \mathrm{Ab}$ & $10.25 \mathrm{Aa}$ & $9.00 \mathrm{Aa}$ & $8.50 \mathrm{Ab}$ & $10.25 \mathrm{Aa}$ & $9.00 \mathrm{Aa}$ \\
\hline Trifloxysulfuron & $10.00 \mathrm{Aa}$ & $10.00 \mathrm{Aa}$ & $9.00 \mathrm{Aa}$ & $10.25 \mathrm{Aa}$ & $10.25 \mathrm{Aa}$ & $8.75 \mathrm{Aa}$ \\
\hline Flumioxazin & $1.25 \mathrm{Bc}^{*}$ & $3.75 \mathrm{Bc}^{*}$ & $9.00 \mathrm{Aa}$ & $1.25 \mathrm{Bc}^{*}$ & $3.50 \mathrm{Bb}^{*}$ & $8.25 \mathrm{Ab}$ \\
\hline Fomesafen & $1.25 \mathrm{Bc}^{*}$ & $0.75 \mathrm{Bd}^{*}$ & $6.75 \mathrm{Ab}$ & $1.00 \mathrm{Bc}^{*}$ & $0.25 \mathrm{Bc}^{*}$ & $6.50 \mathrm{Ab}$ \\
\hline Sulfentrazone & $1.75 \mathrm{Bc}^{*}$ & $6.00 \mathrm{Ab}$ & $7.75 \mathrm{Ab}$ & $2.00 \mathrm{Cc}^{*}$ & $5.25 \mathrm{Bb}^{*}$ & $8.00 \mathrm{Ab}$ \\
\hline Clomazone & $7.25 \mathrm{Bb}$ & $9.75 \mathrm{Aa}$ & $5.75 \mathrm{Bb}$ & $8.50 \mathrm{Ab}$ & $9.75 \mathrm{Aa}$ & $5.75 \mathrm{Bb}$ \\
\hline Isoxaflutole & $7.25 \mathrm{Ab}$ & $8.00 \mathrm{Ab}$ & $6.75 \mathrm{Ab}$ & $7.25 \mathrm{Ab}$ & $8.25 \mathrm{Aa}$ & $6.50 \mathrm{Ab}$ \\
\hline Pendimethalin & $8.75 \mathrm{Ab}$ & $10.25 \mathrm{Aa}$ & 10.50 Аа & $8.50 \mathrm{Ab}$ & $10.50 \mathrm{Aa}$ & $10.50 \mathrm{Aa}$ \\
\hline S-metolachlor & $11.50 \mathrm{Aa}$ & $10.00 \mathrm{Aa}$ & $8.00 \mathrm{Bb}$ & $10.50 \mathrm{Aa}$ & $9.50 \mathrm{Aa}$ & $8.25 \mathrm{Ab}$ \\
\hline Trifluralin & $7.75 \mathrm{Ab}$ & $7.50 \mathrm{Ab}$ & 8.75 Аа & $8.75 \mathrm{Ab}$ & $8.00 \mathrm{Aa}$ & $9.25 \mathrm{Aa}$ \\
\hline Amicarbazone & $1.00 \mathrm{Bc}^{*}$ & $2.25 \mathrm{Bd}^{*}$ & $8.50 \mathrm{Aa}$ & $0.25 \mathrm{Bc}^{*}$ & $1.00 \mathrm{Bc}^{*}$ & $6.75 \mathrm{Ab}$ \\
\hline Atrazine & $1.00 \mathrm{Ac}^{*}$ & $1.00 \mathrm{Ad}^{*}$ & $0.50 \mathrm{Ad}^{*}$ & $0.25 \mathrm{Ac}^{*}$ & $0.25 \mathrm{Ac}^{*}$ & 0.25 Ac* $^{*}$ \\
\hline Diuron & $1.25 \mathrm{Ac}^{*}$ & $0.50 \mathrm{Ad}^{*}$ & $3.25 \mathrm{Ac}^{*}$ & $0.25 \mathrm{Ac}^{*}$ & $0.00 \mathrm{Ac}^{*}$ & $2.25 \mathrm{Ac}^{*}$ \\
\hline Metribuzin & 4.25 $\mathrm{Ac}^{*}$ & $4.75 \mathrm{Ac}^{*}$ & $6.75 \mathrm{Ab}$ & $0.00 \mathrm{Ac}^{*}$ & 0.25 Ac* $^{*}$ & $1.75 \mathrm{Ac}^{*}$ \\
\hline Prometryn & $0.50 \mathrm{Bc}^{*}$ & $3.00 \mathrm{Bc}^{*}$ & $7.75 \mathrm{Ab}$ & $0.75 \mathrm{Bc}^{*}$ & $2.50 \mathrm{Bb}^{*}$ & $6.50 \mathrm{Ab}$ \\
\hline Check & \multicolumn{3}{|c|}{9.25} & \multicolumn{3}{|c|}{9.25} \\
\hline $\mathrm{CV}(\%)$ & \multicolumn{3}{|c|}{28.79} & \multicolumn{3}{|c|}{27.14} \\
\hline
\end{tabular}

* Differ from the check by the Dunnett’s test $(\mathrm{p} \leq 0.05)$; Means followed by different uppercase letters in the lines and lowercase letters in the column differ by the Scott-Knott test $(\mathrm{p} \leq 0.05)$. 
In terms of selectivity, stood out: chlorimuron-ethyl, imazethapyr, trifloxysulfuron-sodium, clomazone, pendimethalin, S-metolachlor and trifluralin, since in the three doses used these were the only treatments applied in preemergence of C. spectabilis which showed no dry matter reduction of plants in relation to the check without herbicide.

Table 4 presents the data from phytotoxicity assessments and E2 stand, in which herbicides were applied in preemergence of $C$. spectabilis in loam texture soil. Inhibitors of PROTOX and PSII were the herbicides that provided the major symptoms of injuries to showy crotalaria plants (both assessments, 7 and 28 DAE), especially when applied in larger doses, also causing reduction in the number of plants per pot.

When comparing experiments 1 and 2 , it is seen that the initial phytotoxicity of C. spectabilis was similar in both soils when herbicides were used in larger doses, except for isoxaflutole, which decreased phytotoxicity levels higher than $40.00 \%$ when applied to the loam texture soil comparing to the clayey (Tables 3 and 4).

The reduction observed in the treatment with the application of isoxaflutole (60 $\mathrm{g} \mathrm{ha}^{-1}$ ) in clayey soil can be explained by the physicochemical characteristics of the product. Isoxaflutole is considered a pro-herbicide, which, after its application, is rapidly converted to diquetonitrila metabolite, which is the biologically active molecule in weed control. The sorption of this herbicide has a correlation with clay and organic carbon in the soil, and there is persistence as these two components increase in the soil (Inoue et al., 2009). The lowest intoxication levels observed in the experiment conducted with clayey soil, in relation to the loam texture soil, may be related to the fact that the amount of this herbicide in the soil solution was lower, due to isoxaflutole being adsorbed to clay.

ALS inhibitors (diclosulan, pyrithiobacsodium, imazethapyr, chlorimuron-ethyl and trifloxysulfuron-sodium), along with clomazone, S-metolachlor and trifluralin exerted low levels of injuries to showy crotalaria plants when applied to loam texture soil, consisting of options that can be studied for use in tillage of the weed community in preemergence of this species. Data from phytotoxicity assessments at 28 DAE of showy crotalaria show that the best alternatives to chemical control in preemergence of C. spectabilis in loam texture soil are amicarbazone, atrazine, metribuzin, diuron, prometryn, isoxaflutole, flumioxazin, fomesafen and sulfentrazone.

An important factor to be highlighted regarding the potential use of some treatments on weed control in showy crotalaria is that, to ensure the selectivity of the herbicide, the application of this one at very low doses would be required, which can not be interesting from the point of view of tillage because the effectiveness of the product may be compromised, since each active ingredient has efficiency over weeds at certain concentrations in soil (Spader \& Vidal, 2000).

With respect to the E2 dry matter data, it appears that even the herbicides that caused low levels of toxicity reduced aboveground mass of showy crotalaria plants when compared to the check without application, showing that often the symptoms caused by herbicides may not be visually noticeable (Table 5).

The showy crotalaria plants that developed in loam texture soil (E2) showed greater accumulation of dry matter, compared with those present in the clayey soil (E1). In treatments where herbicides were not applied (check), showy crotalaria plants dry matter accumulation 3.3 times larger was observed in the loam texture soil in relation to that developed in clayey soil (Table 5). The best development of $C$. spectabilis in the loam texture soil may be related to the chemical properties of this soil, since it has a higher content of organic carbon and $\mathrm{pH}$ most suitable for plant growth, compared to the clayey texture soil. In addition, factors related to soil texture, such as penetration resistance, water retention capacity and availability of $\mathrm{O}_{2}$, may have provided more favorable environment for the development of showy crotalaria in this type of soil (loam). 
Table 4 - Phytotoxicity (\%) and C. spectabilis plant stand at 7 and 28 DAE, due to the application of different herbicides in preemergence in loam texture soil (E2). Maringá, PR - 2012

\begin{tabular}{|c|c|c|c|c|c|c|}
\hline \multirow{2}{*}{ Treatment } & \multicolumn{3}{|c|}{$\%$ of phytotoxicity (7 DAE) } & \multicolumn{3}{|c|}{ \% of phytotoxicity (28 DAE) } \\
\hline & D100 & D50 & D25 & D100 & D50 & D25 \\
\hline Chlorimuron & $31.25 \mathrm{Ad}^{*}$ & $15.00 \mathrm{Be}$ & $16.25 \mathrm{Bd}$ & $31.75 \mathrm{Ac}^{*}$ & $8.25 \mathrm{Bd}$ & $9.25 \mathrm{Bd}$ \\
\hline Diclosulan & 23.25 Ad & $18.75 \mathrm{Ae}$ & $11.75 \mathrm{Ad}$ & 23.00 Ad & $12.50 \mathrm{Ad}$ & $5.00 \mathrm{Ad}$ \\
\hline Flumetsulan & $50.00 \mathrm{Ac}^{*}$ & $34.00 \mathrm{Bd}^{*}$ & $20.00 \mathrm{Bd}$ & $51.75 \mathrm{Ab}^{*}$ & $27.50 \mathrm{Bc}$ & $10.50 \mathrm{Bd}$ \\
\hline Imazethapyr & $7.50 \mathrm{Ae}$ & $6.25 \mathrm{Ae}$ & $7.50 \mathrm{Ad}$ & $2.50 \mathrm{Ad}$ & $1.25 \mathrm{Ad}$ & $1.25 \mathrm{Ad}$ \\
\hline Pyrithiobac & $52.50 \mathrm{Ac}^{*}$ & $31.75 \mathrm{Bd}^{*}$ & $18.75 \mathrm{Bd}$ & $35.00 \mathrm{Ac}^{*}$ & 23.25 Ac & $8.00 \mathrm{Bd}$ \\
\hline Trifloxysulfuron & $35.00 \mathrm{Ad}^{*}$ & $25.00 \mathrm{Ae}^{*}$ & $8.75 \mathrm{Bd}$ & 16.75 Ad & 3.75 Ad & $0.00 \mathrm{Ad}$ \\
\hline Flumioxazin & $92.00 \mathrm{Aa}^{*}$ & $100.00 \mathrm{Aa}^{*}$ & $28.75 \mathrm{Bc}^{*}$ & $90.00 \mathrm{Aa}^{*}$ & $99.25 \mathrm{Aa}^{*}$ & $7.50 \mathrm{Bd}$ \\
\hline Fomesafen & $99.50 \mathrm{Aa}^{*}$ & $98.75 \mathrm{Aa}^{*}$ & $93.50 \mathrm{Aa}^{*}$ & $100.00 \mathrm{Aa}^{*}$ & $82.50 \mathrm{Aa}^{*}$ & 95.25 Аa* \\
\hline Sulfentrazone & $99.75 \mathrm{Aa}^{*}$ & $67.50 \mathrm{Bb}^{*}$ & $40.00 \mathrm{Cc}^{*}$ & $99.50 \mathrm{Aa}^{*}$ & $43.00 \mathrm{Bc}^{*}$ & $21.00 \mathrm{Cc}$ \\
\hline Clomazone & 28.75 Ad* $^{*}$ & $25.00 \mathrm{Ae}^{*}$ & $21.25 \mathrm{Ad}$ & 10.75 Ad & $6.75 \mathrm{Ad}$ & $7.75 \mathrm{Ad}$ \\
\hline Isoxaflutole & $73.75 \mathrm{Ab}^{*}$ & $38.75 \mathrm{Bd}^{*}$ & $39.25 \mathrm{Bc}^{*}$ & 95.25 Aa* & $38.00 \mathrm{Bc}^{*}$ & $27.25 \mathrm{Bc}$ \\
\hline Pendimethalin & $38.00 \mathrm{Ac}^{*}$ & $30.50 \mathrm{Ad}^{*}$ & $20.75 \mathrm{Ad}$ & $54.00 \mathrm{Ab}^{*}$ & $34.25 \mathrm{Bc}^{*}$ & $14.75 \mathrm{Cd}$ \\
\hline S-metolachlor & $26.25 \mathrm{Ad}^{*}$ & $25.50 \mathrm{Ae}^{*}$ & 17.50 Ad & $10.00 \mathrm{Ad}$ & $12.25 \mathrm{Ad}$ & 10.00 Ad \\
\hline Trifluralin & $31.25 \mathrm{Ad}^{*}$ & $14.50 \mathrm{Be}$ & $15.00 \mathrm{Bd}$ & $25.00 \mathrm{Ad}$ & $2.50 \mathrm{Bd}$ & $2.50 \mathrm{Bd}$ \\
\hline Amicarbazone & $96.75 \mathrm{Aa}^{*}$ & $73.75 \mathrm{Bb}^{*}$ & $70.75 \mathrm{Bb}^{*}$ & $100.00 \mathrm{Aa}^{*}$ & $93.75 \mathrm{Aa}^{*}$ & $88.00 \mathrm{Aa}^{*}$ \\
\hline Atrazine & $98.50 \mathrm{Aa}^{*}$ & $91.00 \mathrm{Aa}^{*}$ & $97.00 \mathrm{Aa}^{*}$ & $100.00 \mathrm{Aa}^{*}$ & $100.00 \mathrm{Aa}^{*}$ & $100.00 \mathrm{Aa}^{*}$ \\
\hline Diuron & $99.75 \mathrm{Aa}^{*}$ & $62.00 \mathrm{Bb}^{*}$ & $28.75 \mathrm{Cc}^{*}$ & $100.00 \mathrm{Aa}^{*}$ & $66.25 \mathrm{Bb}^{*}$ & $38.75 \mathrm{Cc}^{*}$ \\
\hline Metribuzin & $94.00 \mathrm{Aa}^{*}$ & $50.00 \mathrm{Bc}^{*}$ & $27.50 \mathrm{Cc}^{*}$ & $98.25 \mathrm{Aa}^{*}$ & $86.75 \mathrm{Aa}^{*}$ & $52.00 \mathrm{Bb}^{*}$ \\
\hline Prometryn & 99.25 $\mathrm{Aa}^{*}$ & $61.25 \mathrm{Bb}^{*}$ & $15.00 \mathrm{Cd}$ & 99.50 Aa* & $59.00 \mathrm{Bb}^{*}$ & $6.25 \mathrm{Cd}$ \\
\hline Check & & 0.00 & & & 0.00 & \\
\hline CV (\%) & & 22.67 & & & 29.26 & \\
\hline \multirow{2}{*}{ Treatment } & \multicolumn{3}{|c|}{ Stand (7 DAE) } & \multicolumn{3}{|c|}{ Stand (28 DAE) } \\
\hline & D100 & D50 & D25 & D100 & D50 & D25 \\
\hline Chlorimuron & $11.00 \mathrm{Aa}$ & $9.50 \mathrm{Aa}$ & $9.00 \mathrm{Aa}$ & 10.75 Аа & $10.25 \mathrm{Aa}$ & $8.50 \mathrm{Aa}$ \\
\hline Diclosulan & $9.00 \mathrm{Aa}$ & $10.75 \mathrm{Aa}$ & $10.75 \mathrm{Aa}$ & $9.00 \mathrm{Aa}$ & $10.75 \mathrm{Aa}$ & $10.50 \mathrm{Aa}$ \\
\hline Flumetsulan & $8.50 \mathrm{Aa}$ & $7.25 \mathrm{Aa}$ & $9.50 \mathrm{Aa}$ & $8.50 \mathrm{Aa}$ & $7.00 \mathrm{Ab}$ & $10.00 \mathrm{Aa}$ \\
\hline Imazethapyr & $8.75 \mathrm{Aa}$ & $7.50 \mathrm{Aa}$ & $8.50 \mathrm{Aa}$ & $9.50 \mathrm{Aa}$ & $7.50 \mathrm{Ab}$ & $9.00 \mathrm{Aa}$ \\
\hline Pyrithiobac & $9.75 \mathrm{Aa}$ & $8.75 \mathrm{Aa}$ & $9.00 \mathrm{Aa}$ & $9.75 \mathrm{Aa}$ & $8.75 \mathrm{Ab}$ & $9.00 \mathrm{Aa}$ \\
\hline Trifloxysulfuron & $11.75 \mathrm{Aa}$ & $9.25 \mathrm{Aa}$ & $9.75 \mathrm{Aa}$ & $10.75 \mathrm{Aa}$ & $8.25 \mathrm{Ab}$ & $10.25 \mathrm{Aa}$ \\
\hline Flumioxazin & $0.50 \mathrm{Bb}^{*}$ & $0.00 \mathrm{Bc}^{*}$ & $3.25 \mathrm{Ac}^{*}$ & $0.50 \mathrm{Ac}^{*}$ & $0.75 \mathrm{Ad}^{*}$ & $3.00 \mathrm{Ab}^{*}$ \\
\hline Fomesafen & $0.50 \mathrm{Ab}^{*}$ & $0.25 \mathrm{Ac}^{*}$ & $1.25 \mathrm{Ac}^{*}$ & $0.00 \mathrm{Ac}^{*}$ & $0.25 \mathrm{Ad}^{*}$ & 0.75 Ac* $^{*}$ \\
\hline Sulfentrazone & $0.25 \mathrm{Bb}^{*}$ & $4.75 \mathrm{Ab}$ & $6.25 \mathrm{Ab}$ & $0.50 \mathrm{Bc}^{*}$ & $4.50 \mathrm{Ac}^{*}$ & $4.75 \mathrm{Ab}^{*}$ \\
\hline Clomazone & $11.00 \mathrm{Aa}$ & $9.50 \mathrm{Aa}$ & $9.00 \mathrm{Aa}$ & $10.75 \mathrm{Aa}$ & $9.25 \mathrm{Ab}$ & $9.50 \mathrm{Aa}$ \\
\hline Isoxaflutole & 10.25 Аа & $12.00 \mathrm{Aa}$ & $10.00 \mathrm{Aa}$ & $5.75 \mathrm{Bb}^{*}$ & $12.25 \mathrm{Aa}$ & $10.00 \mathrm{Aa}$ \\
\hline Pendimethalin & 10.50 Аа & $8.75 \mathrm{Aa}$ & $9.25 \mathrm{Aa}$ & $10.25 \mathrm{Aa}$ & $9.25 \mathrm{Ab}$ & $9.00 \mathrm{Aa}$ \\
\hline S-metolachlor & $11.75 \mathrm{Aa}$ & $9.75 \mathrm{Aa}$ & $9.00 \mathrm{Aa}$ & $12.00 \mathrm{Aa}$ & $10.50 \mathrm{Aa}$ & $11.00 \mathrm{Aa}$ \\
\hline Trifluralin & $10.75 \mathrm{Aa}$ & $9.25 \mathrm{Aa}$ & $11.50 \mathrm{Aa}$ & $10.50 \mathrm{Aa}$ & $9.00 \mathrm{Ab}$ & $11.50 \mathrm{Aa}$ \\
\hline Amicarbazone & $2.25 \mathrm{Bb}^{*}$ & $2.25 \mathrm{Bb}^{*}$ & $5.25 \mathrm{Ab}$ & $0.00 \mathrm{Ac}^{*}$ & $1.50 \mathrm{Ad}^{*}$ & $2.50 \mathrm{Ab}^{*}$ \\
\hline Atrazine & $0.50 \mathrm{Ab}^{*}$ & $3.00 \mathrm{Ab}^{*}$ & $1.00 \mathrm{Ac}^{*}$ & $0.00 \mathrm{Ac}^{*}$ & $0.00 \mathrm{Ad}^{*}$ & 0.00 Ac* $^{*}$ \\
\hline Diuron & $0.25 \mathrm{Bb}^{*}$ & $1.75 \mathrm{Bc}^{*}$ & $4.50 \mathrm{Ab}$ & $0.00 \mathrm{Bc}^{*}$ & $1.25 \mathrm{Bd}^{*}$ & $3.25 \mathrm{Ab}^{*}$ \\
\hline Metribuzin & $2.75 \mathrm{Cb}^{*}$ & $7.25 \mathrm{Ba}$ & $12.00 \mathrm{Aa}$ & $0.75 \mathrm{Bc}^{*}$ & $0.75 \mathrm{Bd}^{*}$ & $10.00 \mathrm{Aa}$ \\
\hline Prometryn & $0.25 \mathrm{Bb}^{*}$ & $3.00 \mathrm{Bb}^{*}$ & $8.75 \mathrm{Aa}$ & $0.25 \mathrm{Cc}^{*}$ & $3.00 \mathrm{Bc}^{*}$ & 8.50 Aa \\
\hline Check & \multicolumn{3}{|c|}{8.50} & \multicolumn{3}{|c|}{10.00} \\
\hline CV (\%) & \multicolumn{3}{|c|}{18.71} & \multicolumn{3}{|c|}{28.25} \\
\hline
\end{tabular}

* Differ from the check by the Dunnett's test $(\mathrm{p} \leq 0.05)$; Means followed by different uppercase letters in the lines and lowercase letters in the column differ by the Scott-Knott test $(\mathrm{p} \leq 0.05)$. 
Table 5 - Dry matter of C. spectabilis plants at 28 DAE due to the application of different herbicides in preemergence. Maringá, PR - 2012

\begin{tabular}{|c|c|c|c|c|c|c|}
\hline \multirow{3}{*}{ Treatment } & \multicolumn{6}{|c|}{ Dry matter (g) } \\
\hline & \multicolumn{3}{|c|}{ E1 - clayey texture } & \multicolumn{3}{|c|}{ E2 - loam texture } \\
\hline & D100 & D50 & D25 & D100 & D50 & D25 \\
\hline Chlorimuron & $0.51 \mathrm{Aa}$ & $0.49 \mathrm{Aa}$ & $0.65 \mathrm{Aa}$ & $1.51 \mathrm{Ab}$ & $2.15 \mathrm{Ab}$ & $1.70 \mathrm{Ab}$ \\
\hline Diclosulan & $0.20 \mathrm{Ab}^{*}$ & $0.28 \mathrm{Ab}$ & $0.39 \mathrm{Ab}$ & $1.53 \mathrm{Bb}$ & $2.47 \mathrm{Aa}$ & $2.48 \mathrm{Ab}$ \\
\hline Flumetsulan & $0.37 \mathrm{Aa}$ & $0.23 \mathrm{Ab}$ & $0.34 \mathrm{Ab}$ & $0.71 \mathrm{Bc}^{*}$ & $0.51 \mathrm{Bc}^{*}$ & $1.68 \mathrm{Ab}$ \\
\hline Imazethapyr & $0.53 \mathrm{Aa}$ & $0.70 \mathrm{Aa}$ & $0.67 \mathrm{Aa}$ & $2.50 \mathrm{Aa}$ & $2.64 \mathrm{Aa}$ & $3.30 \mathrm{Aa}$ \\
\hline Pyrithiobac & $0.21 \mathrm{Ab}$ & $0.34 \mathrm{Aa}$ & $0.36 \mathrm{Ab}$ & $0.78 \mathrm{Bc}^{*}$ & $1.31 \mathrm{Bb}$ & $2.14 \mathrm{Ab}$ \\
\hline Trifloxysulfuron & $0.49 \mathrm{Aa}$ & $0.60 \mathrm{Aa}$ & $0.43 \mathrm{Aa}$ & $2.08 \mathrm{Ab}$ & $1.76 \mathrm{Ab}$ & $2.36 \mathrm{Ab}$ \\
\hline Flumioxazin & $0.05 \mathrm{Bb}^{*}$ & $0.18 \mathrm{Bb}^{*}$ & $0.54 \mathrm{Aa}$ & $0.04 \mathrm{Bd}^{*}$ & $0.01 \mathrm{Bc}^{*}$ & $0.90 \mathrm{Ac}$ \\
\hline Fomesafen & $0.01 \mathrm{Ab}^{*}$ & $0.01 \mathrm{Ab}^{*}$ & $0.27 \mathrm{Ab}$ & $0.00 \mathrm{Ad}^{*}$ & $0.05 \mathrm{Ac}^{*}$ & $0.06 \mathrm{Ad}^{*}$ \\
\hline Sulfentrazone & $0.12 \mathrm{Ab}^{*}$ & $0.13 \mathrm{Ab}^{*}$ & $0.30 \mathrm{Ab}$ & $0.02 \mathrm{Bd}^{*}$ & $0.57 \mathrm{Bc}^{*}$ & $1.28 \mathrm{Ac}$ \\
\hline Clomazone & $0.46 \mathrm{Aa}$ & $0.46 \mathrm{Aa}$ & $0.82 \mathrm{Ba}$ & $2.55 \mathrm{Aa}$ & $2.39 \mathrm{Aa}$ & $2.12 \mathrm{Ab}$ \\
\hline Isoxaflutole & $0.10 \mathrm{Ab}^{*}$ & $0.21 \mathrm{Ab}$ & $0.21 \mathrm{Ab}$ & $0.06 \mathrm{Ad}^{*}$ & $0.77 \mathrm{Ac}^{*}$ & $0.80 \mathrm{Ac}^{*}$ \\
\hline Pendimethalin & 0.39 Аа & $0.63 \mathrm{Aa}$ & $0.58 \mathrm{Aa}$ & $1.12 \mathrm{Ac}$ & $1.60 \mathrm{Ab}$ & $1.93 \mathrm{Ab}$ \\
\hline S-metolachlor & $0.56 \mathrm{Aa}$ & $0.46 \mathrm{Aa}$ & $0.45 \mathrm{Aa}$ & $3.04 \mathrm{Aa}$ & $2.09 \mathrm{Bb}$ & $1.69 \mathrm{Bb}$ \\
\hline Trifluralin & $0.41 \mathrm{Aa}$ & $0.39 \mathrm{Aa}$ & $0.52 \mathrm{Aa}$ & $2.60 \mathrm{Aa}$ & $3.18 \mathrm{Aa}$ & $3.47 \mathrm{Aa}^{*}$ \\
\hline Amicarbazone & $0.01 \mathrm{Ab}^{*}$ & $0.02 \mathrm{Ab}^{*}$ & $0.27 \mathrm{Ab}$ & $0.00 \mathrm{Ad}^{*}$ & $0.03 \mathrm{Ac}^{*}$ & $0.12 \mathrm{Ad}^{*}$ \\
\hline Atrazine & $0.01 \mathrm{Ab}^{*}$ & $0.01 \mathrm{Ab}^{*}$ & $0.01 \mathrm{Ac}^{*}$ & $0.00 \mathrm{Ad}^{*}$ & $0.00 \mathrm{Ac}^{*}$ & $0.00 \mathrm{Ad}^{*}$ \\
\hline Diuron & $0.01 \mathrm{Ab}^{*}$ & $0.00 \mathrm{Ab}^{*}$ & 0.04 Ac* $^{*}$ & $0.00 \mathrm{Ad}^{*}$ & 0.20 Ac* $^{*}$ & $0.40 \mathrm{Ad}^{*}$ \\
\hline Metribuzin & $0.00 \mathrm{Ab}^{*}$ & $0.01 \mathrm{Ab}^{*}$ & $0.06 \mathrm{Ac}^{*}$ & $0.02 \mathrm{Bd}^{*}$ & $0.19 \mathrm{Bc}^{*}$ & $0.91 \mathrm{Ac}$ \\
\hline Prometryn & $0.02 \mathrm{Bb}^{*}$ & $0.09 \mathrm{Bb}^{*}$ & $0.34 \mathrm{Ab}$ & $0.01 \mathrm{Bd}^{*}$ & $0.52 \mathrm{Bc}^{*}$ & $2.31 \mathrm{Ab}$ \\
\hline Check & \multicolumn{3}{|c|}{0.64} & \multicolumn{3}{|c|}{2.07} \\
\hline CV (\%) & \multicolumn{3}{|c|}{66.00} & \multicolumn{3}{|c|}{44.08} \\
\hline
\end{tabular}

* Differ from the check by the Dunnett's test ( $\leq \leq 0.05)$; Means followed by different uppercase letters in the lines and lowercase letters in the column differ by the Scott-Knott test $(\mathrm{p} \leq 0.05)$.

\section{Experiment 3 (E3) - Herbicides applied in postemergence}

The largest initial intoxication levels (3 DAA) of C. spectabilis due to the treatments applied in postemergence were observed with the application of herbicides whose mechanism of action is inhibition of PROTOX, highlighting saflufenacil applied at the highest dose (35 $\left.\mathrm{g} \mathrm{ha}^{-1}\right)$, which provided better performance in controlling showy crotalaria in this first assessment, both when comparison was done among herbicides and for the three assessed doses of this active ingredient (Table 6).

Regarding the performance in control of volunteer plants by the use of herbicides in larger doses, glufosinate-ammonium was the more responsive treatment to the increase of the applied dose, with better control of
C. spectabilis, close to $90.00 \%$. This increase in control imposed by glufosinate-ammonium is related to its mechanism of action, which causes the inhibition of enzyme glutamine synthase, triggering an accelerated accumulation of intracellular $\mathrm{NH}_{4}{ }^{+}$. The association of this $\mathrm{NH}_{4}{ }^{+}$accumulation to broken chloroplast structure results in the inhibition of photosynthesis and subsequent death of the plant cells (Fleck et al., 2001). Thus, the higher the amount of herbicide deposited on the leaf tissue, the greater the symptoms of intoxication shown by showy crotalaria.

Initially (3 DAA), the herbicides that have systemic action caused the lowest levels of phytotoxicity. In this case, the lack of visual symptoms of injury in the showy crotalaria plants should be viewed with caution, in order to relate the behavior to the selectivity of the 
Table 6 - Phytotoxicity (\%) at 3, 7 and 28 DAA and plants dry matter due to the application of different herbicides in postemergence of C. spectabilis. Maringá, PR - 2012

\begin{tabular}{|c|c|c|c|c|c|c|}
\hline \multirow{2}{*}{ Treatment } & \multicolumn{3}{|c|}{ \% of phytotoxicity (3 DAA) } & \multicolumn{3}{|c|}{ \% of phytotoxicity (7 DAA) } \\
\hline & D100 & D75 & D50 & D100 & D75 & D50 \\
\hline Chlorimuron & $3.75 \mathrm{Ad}$ & $0.00 \mathrm{Ag}$ & $0.00 \mathrm{Ag}$ & $40.00 \mathrm{Ad}^{*}$ & $30.00 \mathrm{Bd}^{*}$ & $38.75 \mathrm{Ad}^{*}$ \\
\hline Imazethapyr & $1.25 \mathrm{Ae}$ & $0.00 \mathrm{Ag}$ & $0.00 \mathrm{Ag}$ & $6.25 \mathrm{Af}$ & $6.25 \mathrm{Af}$ & $5.00 \mathrm{Ag}$ \\
\hline Nicosulfuron & $2.50 \mathrm{Ae}$ & $0.00 \mathrm{Ag}$ & $0.00 \mathrm{Ag}$ & $38.75 \mathrm{Ad}^{*}$ & $40.00 \mathrm{Ac}^{*}$ & $23.25 \mathrm{Bf}^{*}$ \\
\hline Pyrithiobac & $0.00 \mathrm{Ae}$ & $0.00 \mathrm{Ag}$ & $0.00 \mathrm{Ag}$ & $23.75 \mathrm{Ae}^{*}$ & $17.50 \mathrm{Ae}^{*}$ & $18.75 \mathrm{Af}^{*}$ \\
\hline Trifloxysulfuron & $1.25 \mathrm{Ae}$ & $0.00 \mathrm{Ag}$ & $0.00 \mathrm{Ag}$ & $30.00 \mathrm{Ae}^{*}$ & $28.00 \mathrm{Ad}^{*}$ & $26.25 \mathrm{Af}^{*}$ \\
\hline Flumiclorac & $40.00 \mathrm{Ac}^{*}$ & $31.25 \mathrm{Bd}^{*}$ & $21.25 \mathrm{Ce}^{*}$ & 51.25 Ac* $^{*}$ & $35.75 \mathrm{Bc}^{*}$ & $21.75 \mathrm{Cf}^{*}$ \\
\hline Flumioxazin & $85.50 \mathrm{Aa}^{*}$ & $80.75 \mathrm{Ba}^{*}$ & $73.00 \mathrm{Cb}^{*}$ & $100.00 \mathrm{Aa}^{*}$ & $100.00 \mathrm{Aa}^{*}$ & $96.25 \mathrm{Aa}^{*}$ \\
\hline Fomesafen & $78.75 \mathrm{Ab}^{*}$ & $77.00 \mathrm{Ab}^{*}$ & $68.75 \mathrm{Bb}^{*}$ & $99.50 \mathrm{Aa}^{*}$ & $93.75 \mathrm{Aa}^{*}$ & $83.25 \mathrm{Bb}^{*}$ \\
\hline Lactofen & $83.25 \mathrm{Ab}^{*}$ & $67.50 \mathrm{Bc}^{*}$ & $53.75 \mathrm{Cc}^{*}$ & $100.00 \mathrm{Aa}^{*}$ & $98.50 \mathrm{Aa}^{*}$ & $98.75 \mathrm{Aa}^{*}$ \\
\hline Saflufenacil & $89.00 \mathrm{Aa}^{*}$ & $83.75 \mathrm{Ba}^{*}$ & $79.00 \mathrm{Ca}^{*}$ & $100.00 \mathrm{Aa}^{*}$ & $99.00 \mathrm{Aa}^{*}$ & $99.25 \mathrm{Aa}^{*}$ \\
\hline Mesotrione & $0.00 \mathrm{Ae}$ & $0.00 \mathrm{Ag}$ & $0.00 \mathrm{Ag}$ & $42.50 \mathrm{Ad}^{*}$ & $43.75 \mathrm{Ac}^{*}$ & $37.50 \mathrm{Ad}^{*}$ \\
\hline Tembotrione & $0.00 \mathrm{Ae}$ & $0.00 \mathrm{Ag}$ & $0.00 \mathrm{Ag}$ & $45.75 \mathrm{Ac}^{*}$ & $42.50 \mathrm{Ac}^{*}$ & $42.50 \mathrm{Ad}^{*}$ \\
\hline Atrazine & $6.00 \mathrm{Ad}$ & $7.50 \mathrm{Af}$ & $6.75 \mathrm{Af}$ & $100.00 \mathrm{Aa}^{*}$ & $98.25 \mathrm{Aa}^{*}$ & $98.50 \mathrm{Aa}^{*}$ \\
\hline Bentazon & $6.00 \mathrm{Ad}$ & $3.75 \mathrm{Af}$ & $6.75 \mathrm{Af}$ & 48.75 Ac* $^{*}$ & $27.50 \mathrm{Bd}^{*}$ & $5.00 \mathrm{Cg}$ \\
\hline Diuron & $0.00 \mathrm{Ae}$ & $0.00 \mathrm{Ag}$ & $0.00 \mathrm{Ag}$ & $96.75 \mathrm{Aa}^{*}$ & $55.00 \mathrm{Bb}^{*}$ & $31.25 \mathrm{Ce}^{*}$ \\
\hline Prometryn & $1.25 \mathrm{Ae}$ & $1.25 \mathrm{Ag}$ & $0.00 \mathrm{Ag}$ & $99.50 \mathrm{Aa}^{*}$ & $98.25 \mathrm{Aa}^{*}$ & $82.50 \mathrm{Bb}^{*}$ \\
\hline 2,4 D-amine & $35.00 \mathrm{Ac}^{*}$ & $30.00 \mathrm{Bd}^{*}$ & $23.75 \mathrm{Ce}^{*}$ & $62.50 \mathrm{Ab}^{*}$ & $48.75 \mathrm{Bb}^{*}$ & $41.25 \mathrm{Bd}^{*}$ \\
\hline Aminocyclopyrachlor & $38.75 \mathrm{Ac}^{*}$ & $31.25 \mathrm{Bd}^{*}$ & $28.75 \mathrm{Bd}^{*}$ & $62.50 \mathrm{Ab}^{*}$ & $55.00 \mathrm{Bb}^{*}$ & $51.25 \mathrm{Bc}^{*}$ \\
\hline Glyphosate & $0.00 \mathrm{Ae}$ & $0.00 \mathrm{Ag}$ & $0.00 \mathrm{Ag}$ & $100.00 \mathrm{Aa}^{*}$ & $100.00 \mathrm{Aa}^{*}$ & $100.00 \mathrm{Aa}^{*}$ \\
\hline Clethodim & $2.50 \mathrm{Ae}$ & $0.00 \mathrm{Ag}$ & $0.00 \mathrm{Ag}$ & $5.50 \mathrm{Af}$ & $6.50 \mathrm{Af}$ & $6.25 \mathrm{Ag}$ \\
\hline Glufosinate-ammonium & $40.00 \mathrm{Ac}^{*}$ & $21.25 \mathrm{Be}^{*}$ & $18.75 \mathrm{Be}^{*}$ & $98.50 \mathrm{Aa}^{*}$ & $96.00 \mathrm{Aa}^{*}$ & $83.75 \mathrm{Bb}^{*}$ \\
\hline Check & \multicolumn{3}{|c|}{0.00} & \multicolumn{3}{|c|}{0.00} \\
\hline $\mathrm{CV}(\%)$ & \multicolumn{3}{|c|}{15.77} & \multicolumn{3}{|c|}{9.26} \\
\hline \multirow{2}{*}{ Treatment } & \multicolumn{3}{|c|}{ \% of phytotoxicity (28 DAA) } & \multicolumn{3}{|c|}{ Dry matter (g) } \\
\hline & D100 & D75 & D50 & D100 & D75 & D50 \\
\hline Chlorimuron & $52.50 \mathrm{Ac}^{*}$ & $40.00 \mathrm{Bc}^{*}$ & $33.75 \mathrm{Be}^{*}$ & $2.04 \mathrm{Ac}^{*}$ & $2.81 \mathrm{Ac}^{*}$ & $3.09 \mathrm{Ad}^{*}$ \\
\hline Imazethapyr & $7.50 \mathrm{Af}$ & $1.25 \mathrm{Ad}$ & $0.00 \mathrm{Ag}$ & $8.13 \mathrm{Aa}$ & $7.50 \mathrm{Aa}$ & $7.14 \mathrm{Ab}$ \\
\hline Nicosulfuron & $50.00 \mathrm{Ac}^{*}$ & $48.75 \mathrm{Ac}^{*}$ & $37.50 \mathrm{Be}^{*}$ & $1.60 \mathrm{Bc}^{*}$ & $1.92 \mathrm{Bd}^{*}$ & $3.13 \mathrm{Ad}^{*}$ \\
\hline Pyrithiobac & $41.25 \mathrm{Ad}^{*}$ & $32.50 \mathrm{Ac}^{*}$ & $22.50 \mathrm{Bf*}$ & $3.87 \mathrm{Ab}^{*}$ & $3.94 \mathrm{Ab}^{*}$ & $4.52 \mathrm{Ac}^{*}$ \\
\hline Trifloxysulfuron & 47.50 $\mathrm{Ad}^{*}$ & $40.00 \mathrm{Ac}^{*}$ & $33.75 \mathrm{Ae}^{*}$ & $1.05 \mathrm{Ad}^{*}$ & $1.26 \mathrm{Ad}^{*}$ & $1.74 \mathrm{Ae}^{*}$ \\
\hline Flumiclorac & $28.25 \mathrm{Ae}^{*}$ & $8.75 \mathrm{Bd}$ & $4.00 \mathrm{Bg}$ & $3.93 \mathrm{Bb}^{*}$ & $4.42 \mathrm{Bb}^{*}$ & $6.45 \mathrm{Ab}^{*}$ \\
\hline Flumioxazin & $100.00 \mathrm{Aa}^{*}$ & $100.00 \mathrm{Aa}^{*}$ & $99.50 \mathrm{Aa}^{*}$ & $0.00 \mathrm{Ad}^{*}$ & $0.00 \mathrm{Ae}^{*}$ & $0.00 \mathrm{Ag}^{*}$ \\
\hline Fomesafen & $99.50 \mathrm{Aa}^{*}$ & $75.00 \mathrm{Bb}^{*}$ & $65.00 \mathrm{Bc}^{*}$ & $0.01 \mathrm{Ad}^{*}$ & $0.69 \mathrm{Ae}^{*}$ & $1.26 \mathrm{Af}^{*}$ \\
\hline Lactofen & $100.00 \mathrm{Aa}^{*}$ & $100.00 \mathrm{Aa}^{*}$ & $100.00 \mathrm{Aa}^{*}$ & $0.00 \mathrm{Ad}^{*}$ & $0.00 \mathrm{Ae}^{*}$ & $0.00 \mathrm{Ag}^{*}$ \\
\hline Saflufenacil & $100.00 \mathrm{Aa}^{*}$ & $97.50 \mathrm{Aa}^{*}$ & $84.50 \mathrm{Bb}^{*}$ & $0.00 \mathrm{Ad}^{*}$ & $0.00 \mathrm{Ae}^{*}$ & $0.47 \mathrm{Ag}^{*}$ \\
\hline Mesotrione & $61.25 \mathrm{Ac}^{*}$ & $55.00 \mathrm{Ac}^{*}$ & $52.50 \mathrm{Ad}^{*}$ & $0.43 \mathrm{Ad}^{*}$ & $1.12 \mathrm{Ad}^{*}$ & $0.83 \mathrm{Af}^{*}$ \\
\hline Tembotrione & $55.00 \mathrm{Ac}^{*}$ & $45.00 \mathrm{Ac}^{*}$ & $43.75 \mathrm{Ae}^{*}$ & $0.83 \mathrm{Ad}^{*}$ & $1.11 \mathrm{Ad}^{*}$ & $1.40 \mathrm{Af}^{*}$ \\
\hline Atrazine & $100.00 \mathrm{Aa}^{*}$ & $100.00 \mathrm{Aa}^{*}$ & $100.00 \mathrm{Aa}^{*}$ & $0.00 \mathrm{Ad}^{*}$ & $0.00 \mathrm{Ae}^{*}$ & $0.00 \mathrm{Ag*}$ \\
\hline Bentazon & $33.75 \mathrm{Ad}^{*}$ & $9.25 \mathrm{Bd}$ & $6.25 \mathrm{Bg}$ & $2.75 \mathrm{Ac}^{*}$ & $3.67 \mathrm{Ab}^{*}$ & $3.43 \mathrm{Ad}^{*}$ \\
\hline Diuron & $100.00 \mathrm{Aa}^{*}$ & $43.75 \mathrm{Bc}^{*}$ & $35.75 \mathrm{Be}^{*}$ & $0.00 \mathrm{Cd}^{*}$ & $1.67 \mathrm{Bd}^{*}$ & 2.79 Ad* \\
\hline Prometryn & $100.00 \mathrm{Aa}^{*}$ & $100.00 \mathrm{Aa}^{*}$ & $100.00 \mathrm{Aa}^{*}$ & $0.00 \mathrm{Ad}^{*}$ & $0.00 \mathrm{Ae}^{*}$ & $0.00 \mathrm{Ag*}$ \\
\hline 2,4 D-amine & $65.00 \mathrm{Ac}^{*}$ & $36.25 \mathrm{Bc}^{*}$ & $37.50 \mathrm{Be}^{*}$ & $1.99 \mathrm{Ac}^{*}$ & $2.70 \mathrm{Ac}^{*}$ & $2.50 \mathrm{Ae}^{*}$ \\
\hline Aminocyclopyrachlor & $76.25 \mathrm{Ab}^{*}$ & $65.00 \mathrm{Bb}^{*}$ & $58.75 \mathrm{Bd}^{*}$ & $0.78 \mathrm{Cd}^{*}$ & $2.35 \mathrm{Bc}^{*}$ & $3.54 \mathrm{Ad}^{*}$ \\
\hline Glyphosate & $100.00 \mathrm{Aa}^{*}$ & $100.00 \mathrm{Aa}^{*}$ & $100.00 \mathrm{Aa}^{*}$ & $0.00 \mathrm{Ad}^{*}$ & $0.00 \mathrm{Ae}^{*}$ & $0.00 \mathrm{Ag}^{*}$ \\
\hline Clethodim & $0.00 \mathrm{Af}$ & $0.00 \mathrm{Ad}$ & $0.00 \mathrm{Ag}$ & $8.36 \mathrm{Aa}$ & $7.60 \mathrm{Aa}$ & $8.26 \mathrm{Aa}$ \\
\hline Glufosinate-ammonium & $100.00 \mathrm{Aa}^{*}$ & $100.00 \mathrm{Aa}^{*}$ & $100.00 \mathrm{Aa}^{*}$ & $0.00 \mathrm{Ad}^{*}$ & $0.00 \mathrm{Ae}^{*}$ & $0.00 \mathrm{Ag}^{*}$ \\
\hline Check & \multicolumn{3}{|c|}{0.00} & \multicolumn{3}{|c|}{8.34} \\
\hline $\mathrm{CV}(\%)$ & \multicolumn{3}{|c|}{12.83} & \multicolumn{3}{|c|}{33.91} \\
\hline
\end{tabular}

* Differ from the check by the Dunnett's test $(\mathrm{p} \leq 0.05)$; Means followed by different uppercase letters in the lines and lowercase letters in the column differ by the Scott-Knott test $(\mathrm{p} \leq 0.05)$. 
treatments, as these products require more time to be able to reach the action apex in the plant.

At 7 DAA, up to $80.00 \%$ of injury were observed in the showy crotalaria plants to which were applied herbicides inhibiting PROTOX, along with glufosinate-ammonium, glyphosate, atrazine and diuron, the latter being mostly applied only in the higher dose. The high levels of injury posed by herbicides that have contact action are related to the morphology of the showy crotalaria plants when they were submitted to the application of the treatments; as the application stage was of three true leaves, the plants still had little wax deposition in the epidermis of the leaves, which caused the desiccation to be more pronounced compared to plants in more advanced stages of development. This fact can be confirmed by analyzing the control data observed for flumioxazin and those described in the literature, in which the authors, working with doses up to $60 \mathrm{~g} \mathrm{ha}^{-1}$ of that herbicide on adult plants (full bloom) of C. spectabilis, observed injury levels lower than $40.00 \%$ (Inoue et al., 2012).

Herbicides chlorimuron-ethyl, nicosulfuron and trifloxysulfuron-sodium (ALS inhibitors), mesotrione and tembotrione (carotenoid synthesis inhibitors) and 2,4-D amine and aminocyclopyrachlor, despite having exercised high levels of phytotoxicity, aiming to use in the tillage of volunteer plants, had not performed well in controlling this species of showy crotalaria (Table 6). Still, the injuries caused by the doses assessed in these treatments have not qualified either as potential for selective herbicides for C. spectabilis, since the inhibition level in the development would compromise the farm exploitation of this legume.

At $7 \mathrm{DAA}$, the treatments that caused minor injuries to showy crotalaria plants in applications done in postemergence were imazethapyr, clethodim, pyrithiobac-sodium and bentazon, in descending order of selectivity for this analyzed variable-response.

At the last assessment of phytotoxicity (28 DAA), herbicides atrazine, flumioxazin, lactofen, saflufenacil, glyphosate and glufosinate-ammonium, regardless of the applied dose, controlled all showy crotalaria plants receiving the application of these treatments, proving to be good alternatives for tillage of this species when infesting other crops (Table 6).

Fomesafen, when applied at the highest dose $\left(250 \mathrm{~g} \mathrm{ha}^{-1}\right)$, showed the same efficiency of the treatments described above; however, when $187.5 \mathrm{~g} \mathrm{ha}^{-1}$ of this herbicide were applied, the levels of control of C. spectabilis were unsatisfactory, showing that this reduction in control, compared to the previous assessment (7 DAA), was caused by the presence of regrowth plants.

Regarding diuron performance, it appears that the application of $2,000 \mathrm{~g} \mathrm{ha}^{-1}$ caused the death of all C. spectabilis plants; however, for the lower dose of this herbicide $\left(1,500 \mathrm{~g} \mathrm{ha}^{-1}\right)$, the control levels were much lower than that required to achieve a satisfactory level (46.25\%). These data indicate that when choosing to use diuron in the control of volunteer plants of this species of showy crotalaria, it is essential to ensure the correct disposal of the amount of active ingredient recommended at the time of application, for the reduction of a quarter of the dose of this herbicide made control levels to be reduced to values above $50.00 \%$ (Table 6).

2,4-D amine applied alone has low efficiency in the control of showy crotalaria, both when aimed at controlling voluntary or adult plants (crop preseeding tillage). In a study described in the literature, the application of this herbicide in doses of up to 3,350 $\mathrm{g} \mathrm{ha}^{-1}$ on showy crotalaria plants in full bloom promoted control lower than $70.00 \%$ (Oliveira Neto et al., $2011 \mathrm{~b})$. For the use of 2,4-D amine in the tillage of $C$. spectabilis to be effective, it is essential to mix this one with other herbicides, for some products in combination with 2,4-D amine exhibit synergism, which will result in an increase in the species control levels (Takano et al., 2013).

C. spectabilis plants which received postemergence application of imazethapyr and clethodim (all doses), flumiclorac and bentazon (D75 and D50) and pyrithiobac-sodium (D50) showed the lowest levels of injuries in the final assessment of intoxication. Table 6 shows the dry matter data for the $C$. spectabilis 
plants at 28 DAA of the herbicides. Similarly to that observed in experiments with herbicide in preemergence, the biggest reductions in dry matter accumulation were observed in treatments that have exerted greater injuries to showy crotalaria plants.

Some treatments showed no potential to be used even to control showy crotalaria volunteer plants or to be placed on weed tillage in this (selective) crop. Nevertheless, it is noteworthy that the suppression imposed by these herbicides in C. spectabilis (reduced dry matter accumulation) reduces competition of these volunteer plants with the crops in which they develop, due to the small size of the plants.

\section{Selection of herbicides for use in systems grown with $C$. spectabilis}

Table 7 summarizes the findings in the three experiments, with the herbicides that can be positioned to control C. spectabilis volunteer plants infesting the main crops of agricultural interest in Brazil. The inclusion of a particular herbicide in this table for recommendation in a crop is related to the level of control exercised, which must be equal to or greater than $80.00 \%$, as recommended by SBCPD (Sociedade Brasileira da Ciência das Plantas Daninhas; Brazilian Society of Weed Science) (1995), as being considered satisfactory. Currently, this value is adopted by the Ministério da Agricultura, Pecuária e Abastecimento (MAPA) for purposes of herbicides logs in Brazil.

Regarding the herbicides that showed potential to be selective to $C$. spectabilis, in Table 8 were summarized the results found in all experiments, with the herbicides that can be assessed for the recommendation of the weed community tillage in $C$. spectabilis crops. The inclusion of a particular herbicide in this table is related to the level of phytotoxicity exercised, which must be equal to or less than $25.00 \%$, in addition to not having affected the stand variables and dry matter accumulation (for experiments 1 and 2), since both are indicative that the product, when applied in preemergence, will not compromise the initial development of the crop. To include the treatments applied in postemergence of showy crotalaria as possible herbicides to be studied in selectivity experiments, the level of phytotoxicity exerted was considered, which

Table 7 - Herbicides with potential for use in different crops, in order to control C. spectabilis volunteer plants. Maringá, PR - 2012

\begin{tabular}{|c|c|c|c|}
\hline \multirow{3}{*}{ Crop $^{\underline{1}}$} & \multicolumn{3}{|c|}{ Application mode } \\
\hline & \multicolumn{2}{|c|}{ Preemergence } & \multirow{2}{*}{ Postemergence } \\
\hline & Clayey texture & Loam texture & \\
\hline Cotton plant & $\begin{array}{l}\text { diuron** } \\
\text { fomesafen** } \\
\text { prometryn* }\end{array}$ & $\begin{array}{l}\text { diuron* } \\
\text { fomesafen*** } \\
\text { isoxaflutole* } \\
\text { prometryn* }\end{array}$ & $\begin{array}{l}\text { glufosinate- } \\
\text { ammonium }^{2 / * * *} \\
\text { diuron* } \\
\text { flumioxazin*** } \\
\text { glyphosate }^{2 / * * *}\end{array}$ \\
\hline Sugarcane & $\begin{array}{l}\text { amicarbazone* } \\
\text { atrazine*** } \\
\text { diuron** } \\
\text { metribuzin** } \\
\text { sulfentrazone* }\end{array}$ & $\begin{array}{l}\text { amicarbazone*** } \\
\text { atrazine*** } \\
\text { diuron* } \\
\text { flumioxazin** } \\
\text { isoxaflutole* } \\
\text { metribuzin** } \\
\text { sulfentrazone* }\end{array}$ & $\begin{array}{l}\text { atrazine*** } \\
\text { diuron* } \\
\text { saflufenacil*** }\end{array}$ \\
\hline Beans plant & & flumioxazin** & fomesafen* \\
\hline Maize & $\begin{array}{l}\text { amicarbazone* } \\
\text { atrazine*** }\end{array}$ & $\begin{array}{l}\text { amicarbazone*** } \\
\text { atrazine*** } \\
\text { isoxaflutole* }\end{array}$ & $\begin{array}{l}\text { glufosinate- } \\
\text { ammonium }^{2 / * * *} \\
\text { atrazine } \\
\text { glyphosate }^{2 / * * *}\end{array}$ \\
\hline Soybean & $\begin{array}{l}\text { metribuzin** } \\
\text { sulfentrazone* }\end{array}$ & $\begin{array}{l}\text { flumioxazin** } \\
\text { metribuzin** } \\
\text { sulfentrazone* }\end{array}$ & $\begin{array}{l}\text { glufosinate- } \\
\text { ammonium }^{2 * * *} \\
\text { fomesafen* }^{*} \\
\text { glyphosate }{ }^{2 / * * *} \\
\text { lactofen*** }\end{array}$ \\
\hline Wheat & metribuzin** & metribuzin** & - \\
\hline
\end{tabular}

${ }^{1 /}$ Do not exceed the recommended doses in the package leaflet of the commercial formulation used for the crop; ${ }^{2}$ 'Registered for genetically modified crop with insertion of the gene that confers resistance to the herbicide recommended; * Recommended only at the highest dose assessed in the study; ** Recommended in the two highest doses assessed at the study; *** Recommended at all doses assessed at the study.

Table 8 - Herbicides that showed potential to be used for weed tillage in the C. spectabilis crop. Maringá, PR - 2012

\begin{tabular}{|c|c|c|}
\hline \multicolumn{3}{|c|}{ Application mode } \\
\hline \multicolumn{2}{|c|}{ Preemergence } & \multirow{2}{*}{ Postemergence } \\
\hline Clayey texture & Loam texture & \\
\hline $\begin{array}{c}\text { Chlorimuron } \\
\text { Imazethapyr } \\
\text { Trifloxysulfuron- } \\
\text { sodium } \\
\text { Pendimethalin } \\
\text { S-metolachlor } \\
\text { Trifluralin }\end{array}$ & $\begin{array}{l}\text { chlorimuron } \\
\text { diclosulan } \\
\text { imazethapyr } \\
\text { pyrithiobac-sodium } \\
\text { trifloxysulfuron- } \\
\text { sodium } \\
\text { clomazone } \\
\text { S-metolachlor } \\
\text { trifluralin }\end{array}$ & $\begin{array}{c}\text { imazethapyr } \\
\text { pyrithiobac-sodium } \\
\text { flumiclorac } \\
\text { bentazon } \\
\text { clethodim }\end{array}$ \\
\hline
\end{tabular}


must be equal to or less than $25.00 \%$ in at least one of the doses assessed, besides the subsequent recovery from the injuries caused to plants by the herbicides.

Importantly, as in experiments with herbicides applied in preemergence (E1 and E2) there was a variation in soil texture (and consequently the other characteristics of the edaphic environment), there was variation in herbicides that had the potential to be selective, and it was necessary to conduct dose-response studies for each soil type in order to ensure the selectivity of each herbicide.

Herbicides that showed greater selectivity for C. spectabilis plants when applied in postemergence were imazethapyr and clethodim, since the injuries caused by these treatments did not exceed amounts equivalent to $10.00 \%$. Bentazon and flumiclorac, although when applied to D100 they have provided high levels of phytotoxicity, in the other two doses assessed (D75 and D50) provided lower levels of injuries. Regarding pyrithiobac-sodium, this one exerted few injuries to showy crotalaria plants only when applied at the lowest dose (D50). Although this dose of pyrithiobac-sodium is equivalent to $50.00 \%$ of the log dose for cotton plant, when there are control studies data available in the literature about the use of this active ingredient, it is observed that in D50 (pyrithiobac-sodium $56 \mathrm{~g} \mathrm{ha}^{-1}$ ) the product has effectiveness in tillage of several dicotyledonous weed species (Braz et al., 2011, 2012).

Amicarbazone, atrazine, diuron, metribuzin, prometryn, fomesafen and sulfentrazone showed effectiveness for control in preemergence of $C$. spectabilis in clayey soil. In addition to these, for loam texture soils, flumioxazin and isoxaflutole also showed potential for use in control of showy crotalaria prior to its emergence. In the case of herbicides applied in postemergence that can be used aiming chemical control of C. spectabilis, atrazine, diuron, prometryn, flumioxazin, fomesafen, lactofen, saflufenacil, glufosinate-ammonium and glyphosate stand out.

Herbicides chlorimuron-ethyl, diclosulan, imazethapyr, pyrithiobac-sodium, trifloxysulfuron-sodium, clomazone, pendimethalin, S-metolachlor and trifluralin, applied in preemergence, and imazethapyr, pyrithiobac-sodium, flumiclorac, bentazon and clethodim, applied in postemergence, caused low levels of injuries to $C$. spectabilis plants and have potential to be assessed in herbicide selection programs for this species.

\section{ACKNOWLEDGEMENTS}

Partial funding for this work was provided by CNPq (Conselho Nacional de Desenvolvimento Científico e Tecnológico).

\section{LITERATURE CITED}

BALESDENT, J.; CHENU, C.; BALABANE, M. Relationship of soil organic matter dynamics to physical protection and tillage. Soil Till Res., v. 53, n. 3/4, p. 215-230, 2000.

BARRETO, A. C.; FERNANDES, M. F. Recomendações técnicas para o uso da adubação verde em solos de tabuleiros costeiros. Aracaju: Embrapa Tabuleiros Costeiros, 2001. 7 p. (Circular Técnica, 19)

BRAZ, G. B. P. et al. Alternativas para o controle de soja RR ${ }^{\circledR}$ voluntária na cultura do algodoeiro. Biosci. J., v. 29, n. 2, p. 360-369, 2013.

BRAZ, G. B. P. et al. Performance of cotton herbicide treatments for Amaranthus lividus and Amaranthus hybridus. R. Bras. Herbic., v. 11, n. 1, p. 1-10, 2012.

BRAZ, G. B. P. et al. Controle de solanáceas por herbicidas utilizados em algodoeiro. R. Bras. Herbic., v. 10, n. 3, p. 190-199, 2011.

CARVALHO, S. R. L. et al. Cinética do crescimento de leguminosas e gramíneas com alto poder relativo de penetração de raízes em solo coeso dos tabuleiros costeiros do recôncavo Baiano (Etapa I). Magistra, v. 15, n. 2, p. 155-164, 2003.

DAN, H. A. et al. Tolerância do cultivar de milheto ADR-300 ao herbicida atrazine. R. Ci. Agron., v. 42, n. 1, p. 193-198, 2011.

FIALHO, C. M. T. et al. Teor foliar de nutrientes em plantas daninhas e de café cultivadas em competição.

Planta Daninha, v. 30, n. 1, p. 65-73, 2012.

FLECK, N. G. et al. Ação dos herbicidas atrazine e glufosinate de amônio no aproveitamento de nitrogênio pelas plantas de milho. Planta Daninha, v. 19, n. 2, p. 235-245, 2001. 
GASPARIM, E. et al. Temperatura no perfil do solo utilizando duas densidades de cobertura e solo nu. Acta Sci. Agron., v. 27, n. 1, p. 107-115, 2005.

INOUE, M. H. et al. Eficácia de herbicidas aplicados em plantas adultas de Crotalaria spectabilis e Crotalaria ochroleuca. R. Bras. Herbic., v. 11, n. 2, p. 148-58, 2012.

INOUE, M. H. et al. Bioavailability of diuron, imazapic and isoxaflutole in soils of contrasting textures. J. Environ. Sci.Health, Part B, v. 44, n. 8, p. 757-763, 2009.

MACIEL, C. D. G. et al. Seletividade e eficácia de herbicidas inibidores da enzima ACCase na cultura da mamona. Planta Daninha, v. 29, n. 3, p. 609-616, 2011.

\section{MADDOX, V.; WESTBROOKS, R.; BYRD, J. D. Showy}

Rattlebox. Mississippi State Extension Service. 2001. Disponível em: <http://www.gri.msstate.edu/ipams/ FactSheets/Showy_rattlebox.pdf $>$. Acesso em: 12 mar. 2014.

MONQUERO, P. A. Plantas transgênicas resistentes aos herbicidas: situação e perspectivas. Bragantia, v. 64, n. 4, p. 517-531, 2005.

OLIVEIRA NETO, A. M. et al. Seletividade de herbicidas aplicados em pré-emergência na cultura do crambe. R. Bras. Herbic., v. 10, n. 1, p. 49-56, 2011 a.

OLIVEIRA NETO, A. M. et al. Manejo químico de adubos verdes para sucessão da cana-de-açúcar em sistema de cultivo mínimo. R. Bras. Herbic., v. 10, n. 2, p. 86-94, 2011b.
OLIVEIRA JR, M. F.; BRIGHENTI, A. M. Comportamento dos herbicidas no ambiente. In: OLIVEIRA JR., R. S.; CONSTANTIN, J.; INOUE, M. H. (Eds.). Biologia e manejo de plantas daninhas. Curitiba: Omnipax, 2011. p. 263-304.

PEIXOTO, A. R. et al. Hospedeiros alternativos de Xanthomonas campestris pv. viticola. Fitopatol. Bras., v. 32, n. 2, p. 161-164, 2007.

RODRIGUES, B. N.; ALMEIDA, F. S. Guia de herbicidas. Londrina: Edição dos Autores, 2011. 697 p.

SOCIEDADE BRASILEIRA DA CIÊNCIA DAS PLANTAS DANINHAS - SBCPD Procedimentos para instalação, avaliação e análise de experimentos com herbicidas. Londrina: 1995. $42 \mathrm{p}$

SPADER, V.; VIDAL, R. A. Eficácia de herbicidas graminicidas aplicados em pré-emergência no sistema de semeadura direta do milho. Planta Daninha, v. 18, n. 2, p. 373-380, 2000.

TAKANO, H. K. et al. Efeito da adição do 2,4-D ao glyphosate para o controle de espécies de plantas daninhas de difícil controle. R. Bras. Herbic., v. 12, n. 1, p. 1-13, 2013.

WILLS, G. D.; MCWHORTER, C. G. Effect of environment on the translocation and toxicity of acifluorfen to showy crotalaria (Crotalaria spectabilis). Weed Sci., v. 29, n. 4, p. 397-401, 1981.

ZABLOTOWICZ, R. M.; WEAVER, M. A.; LOCKE, M. A. Microbial adaptation for accelerated atrazine mineralization/ degradation in Mississippi Delta soils. Weed Sci., v. 54, n. 3, p. 538-547, 2006. 